\title{
Ocular Involvement in Relapsing Polychondritis
}

\author{
Ken Fukuda ${ }^{1, *(\mathbb{D})}$, Tomoka Mizobuchi ${ }^{1}$, Isana Nakajima ${ }^{1}$, Tatsuma Kishimoto ${ }^{1} \mathbb{D}$, Yusaku Miura $^{1}$ and \\ Yoshinori Taniguchi ${ }^{2}$
}

1 Department of Ophthalmology and Visual Science, Kochi Medical School, Kochi University, Nankoku, Kochi 783-8505, Japan; jm-t.yamamoto@kochi-u.ac.jp (T.M.); jm-i-nakajima@kochi-u.ac.jp (I.N.); t.kishimoto@kochi-u.ac.jp (T.K.); miurasaku@kochi-u.ac.jp (Y.M.)

2 Department of Endocrinology, Metabolism, Nephrology and Rheumatology, Kochi Medical School Hospital, Kochi University, Nankoku, Kochi 783-8505, Japan; taniguchiy@kochi-u.ac.jp

* Correspondence: k.fukuda@kochi-u.ac.jp; Tel.: +81-88880-2391

check for updates

Citation: Fukuda, K.; Mizobuchi, T.; Nakajima, I.; Kishimoto, T.; Miura, Y.; Taniguchi, Y. Ocular Involvement in Relapsing Polychondritis. J. Clin. Med. 2021, 10, 4970. https://doi.org/ $10.3390 /$ jcm10214970

Academic Editor:

Andrzej Grzybowski

Received: 28 September 2021

Accepted: 21 October 2021

Published: 26 October 2021

Publisher's Note: MDPI stays neutral with regard to jurisdictional claims in published maps and institutional affiliations.

Copyright: (C) 2021 by the authors. Licensee MDPI, Basel, Switzerland. This article is an open access article distributed under the terms and conditions of the Creative Commons Attribution (CC BY) license (https:/ / creativecommons.org/licenses/by/ $4.0 /)$.

\begin{abstract}
Relapsing polychondritis (RPC) is a rare systemic immune-mediated disease characterized by recurrent inflammation of cartilaginous and proteoglycan-rich tissues throughout the body. Auricular, nasal, tracheal, and articular chondritis and arthritis are common systemic symptoms in patients with RPC. Ocular tissues are also targets of inflammation in RPC, and a variety of ocular symptoms are observed in approximately half of the patients with RPC. Scleritis/episcleritis, uveitis, and conjunctivitis are common symptoms associated with RPC. Less frequently, keratitis, retinopathy, optic neuropathy, muscle palsy, and orbital inflammation are also observed. Ocular inflammation could also be the first manifestation of RPC. Although RPC is a potentially fatal and sight-threatening disease, the rarity of the disease and its protean clinical presentation may lead to delayed diagnosis or misdiagnosis. Given the high prevalence of ocular involvement in RPC, to avoid misdiagnosis, physicians should be suspicious of RPC when they see patients with recurrent ocular inflammatory conditions and various systemic symptoms. In this article, we provide a comprehensive review of ocular manifestations associated with RPC.
\end{abstract}

Keywords: relapsing polychondritis; scleritis; uveitis; keratitis; conjunctivitis; retinopathy; optic neuropathy; ultrasonography; auricular chondritis

\section{Introduction}

Relapsing polychondritis (RPC) was first described by Jaksch-Wartenhorst [1] in 1923 as a rare systemic immune-mediated disease of unknown etiology characterized by recurrent inflammation of cartilaginous and proteoglycan-rich tissues throughout the body [2-4]. The incidence of RPC is estimated to be 3.5 per million population per year in the United States, and a population-based cohort study showed that the incidence of RPC between 1990 and 2012 was 0.71 per million population per year in the United Kingdom [5,6]. A recent calculated prevalence of RPC was 4.5 per million in the United States [7]. The target tissues of RPC include not only cartilaginous structures, such as the ear, nose, respiratory tract, and joints, but also non-cartilaginous tissues, such as the eyes, skin, heart, and central nervous system. Although the pathogenesis of RPC has not been fully elucidated, autoimmune reactions to type II collagen are considered essential, and both humoral and cellular immunity have been implicated in the autoimmune reactions. The rarity and wide spectrum of clinical symptoms and signs of RPC often lead to misdiagnosis or delayed diagnosis [8,9]. Given that RPC is a potentially fatal disease, prompt and correct diagnosis and treatment are essential. The eyeball and ocular adnexa are important target tissues for RPC-induced inflammation, and a wide range of ocular manifestations are observed in patients with RPC (Table 1) $[10,11]$. In this review, we provide an updated, comprehensive review of ocular manifestations in patients with RPC. 
Table 1. Ocular manifestations in patients with RPC.

\begin{tabular}{cc}
\hline Eye Lid & Lid Edema, Ptosis, Tarsitis, Horner's Syndrome \\
\hline Conjunctiva & Conjunctivitis, keratoconjunctivitis sicca \\
\hline Cornea & Ulceration, peripheral thinning, infiltrates, perforation \\
\hline Sclera & Scleritis, episcleritis, scleromalacia \\
\hline Uvea & Uveitis \\
\hline Lens & Cataract \\
\hline Retina & $\begin{array}{r}\text { Retinopathy, retinal vein and artery occlusion, retinal detachment, } \\
\text { Cystoid macular edema, choroiditis }\end{array}$ \\
\hline Optic nerve & Optic neuritis, optic perineuritis, ischemic optic neuropathy, Papilledema \\
\hline Orbit & Orbital inflammation, proptosis \\
\hline Others & Dacryocystitis, extraocular muscle palsies \\
\hline
\end{tabular}

\section{Ocular Manifestations of RPC}

The cumulative prevalence of the ocular symptoms in RPC varies by studies, but they have been reportedly observed in 20-61\% of patients with RPC (Table 2) [2,4,6-9,12-18]. Common ocular manifestations are scleritis, uveitis, conjunctivitis, and keratitis (Table 3). Other ocular manifestations, including eyelid edema, proptosis, retinopathy, optic neuropathy, orbital inflammation, and extraocular muscle palsy, have been reported. Ophthalmologists should be aware that ocular symptoms are one of the common initial symptoms prior to diagnosis, as shown in Table 2. A recent, large study showed that the initial symptoms were ocular symptoms, such as redness and blurred vision in $11.5 \%$ of patients with RPC [13]. In addition, ocular symptoms, such as panuveitis and keratitis [19], keratouveitis [20], retinal occlusive vasculitis [21], oculomotor and abducens nerve palsies [22], recurrent optic perineuritis [23], and orbital inflammation [24,25], have been reported as the first manifestations of RPC before systemic symptoms.

Table 2. Incidence of ocular involvement in cases of RPC in a large case series.

\begin{tabular}{|c|c|c|c|c|c|}
\hline & \multirow{2}{*}{$\begin{array}{c}\text { Number of } \\
\text { Patients }\end{array}$} & \multirow{2}{*}{ Country } & \multirow{2}{*}{ Study Design } & \multicolumn{2}{|c|}{ Ocular Inflammation } \\
\hline & & & & Initial & Cumulative \\
\hline Cao et al., 2021 [12] & 181 & China & Retrospective & & $38 \%$ \\
\hline Chen et al., 2021 [13] & 295 & China & Retrospective & & $46 \%$ \\
\hline Zhang et al., 2021 [14] & 126 & China & Retrospective & $20 \%$ & $27 \%$ \\
\hline Ferrada et al., 2018 [15] & 304 & International & Survey & $40 \%$ & $53 \%$ \\
\hline Dion et al., 2016 [16] & 142 & France & Retrospective & & $56 \%$ \\
\hline Lin et al., 2016 [8] & 158 & China & Retrospective & $11 \%$ & $44 \%$ \\
\hline Hazra et al., 2015 [6] & 50 & U.K. & Retrospective & & $20 \%$ \\
\hline Oka et al., 2014 [17] & 239 & Japan & Survey & $9 \%$ & $46 \%$ \\
\hline Mathew et al., 2012 [7] & 43 & USA & Retrospective & & $57 \%$ \\
\hline Trentham et al.,1998 [9] & 66 & USA & Retrospective & $24 \%$ & $57 \%$ \\
\hline Zeuner et al., 1997 [18] & 62 & German & Survey & $32 \%$ & $50 \%$ \\
\hline Michet et al., 1986 [4] & 112 & USA & Retrospective & $19 \%$ & $51 \%$ \\
\hline McAdam et al., 1976 [2] & 23 & USA & Retrospective & $9 \%$ & $61 \%$ \\
\hline
\end{tabular}


Table 3. Incidence of major ocular manifestations in four large case series.

\begin{tabular}{ccccc}
\hline & $\begin{array}{c}\text { McAdam et al., } \\
\text { 1976 [2] }\end{array}$ & $\begin{array}{c}\text { Issak et al., } \\
\mathbf{1 9 8 6}[10]\end{array}$ & $\begin{array}{c}\text { Zeuner et al., } \\
\text { 1997 [18] }\end{array}$ & $\begin{array}{c}\text { Oka et al., } \\
\text { 2014 [17] }\end{array}$ \\
\hline Number of Patients & 159 & 112 & 62 & 239 \\
Total ocular symptoms & $65 \%$ & $51 \%$ & $50 \%$ & $46 \%$ \\
Scleritis/Episcleritis & $41 \%$ & $47 \%$ & $23 \%$ & $26 \%$ \\
Conjunctivitis & $35 \%$ & $5 \%$ & $24 \%$ & $15 \%$ \\
Uveitis & $26 \%$ & $9 \%$ & $3 \%$ & $11 \%$ \\
Corneal infiltrate/thinning & - & $7 \%$ & - & - \\
Retinopathy & - & $8 \%$ & - & - \\
Optic neuropathy/neuritis & $4 \%$ & $6 \%$ & - & - \\
Eyelid edema & - & $8 \%$ & - & \\
Orbital inflammation & - & $5 \%$ & - & - \\
Extraocular muscle palsy & $4 \%$ & $4 \%$ & - & \\
\hline
\end{tabular}

\subsection{Sclera}

Scleritis/episcleritis is the most common ocular complication associated with RPC (Table 3) [10,26-34]. Most cases of scleritis occur bilaterally. Several case series revealed that diffuse anterior scleritis was the most common (Figure 1), but nodular (Figure 2A) or necrotizing anterior scleritis and posterior scleritis (Figure 2B) were also observed (Table 4) [32-35]. Sainz-de-la-Maza et al. compared patients with scleritis associated with RPC and other systemic immune-mediated diseases and showed that it is more often bilateral, recurrent, necrotizing, and associated with visual disturbance than scleritis associated with other systemic immune-mediated diseases [32].
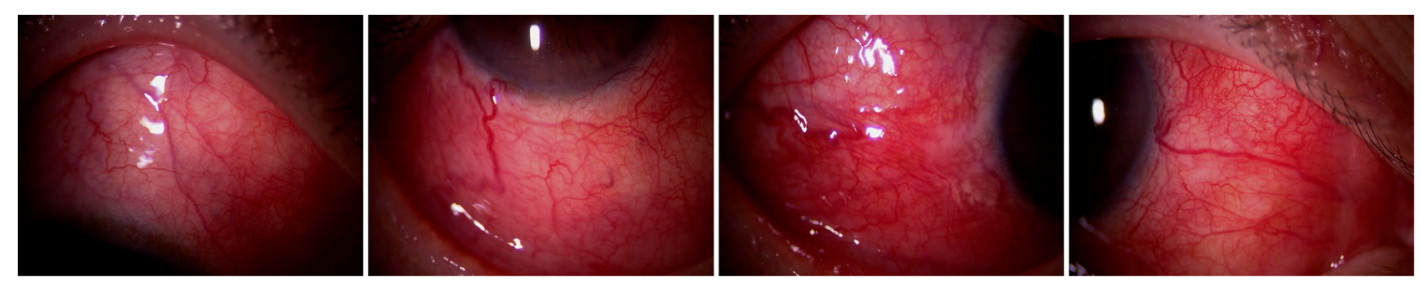

Figure 1. Diffuse anterior scleritis associated with RPC.
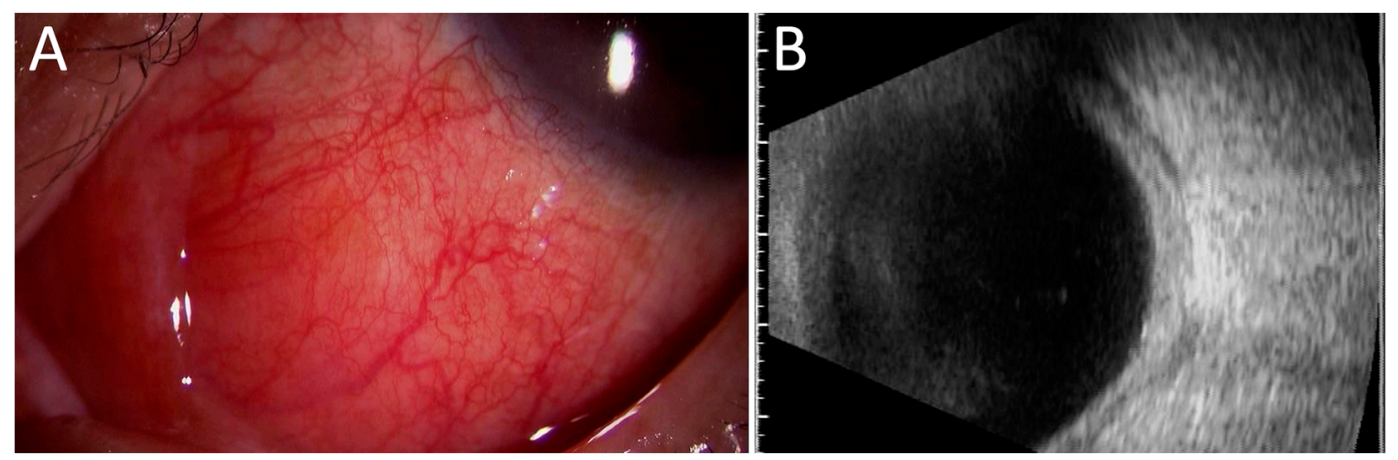

Figure 2. Nodular anterior and posterior scleritis associated with RPC: slit-lamp exam showed anterior nodular scleritis (A) and B-scan ultrasonogram (B) showed thickened sclera with fluid in the sub-Tenon's space (T-sign). 
Table 4. Types of scleritis in previous case series.

\begin{tabular}{ccccccc}
\hline & \multirow{2}{*}{$\begin{array}{c}\text { Number of } \\
\text { Patients }\end{array}$} & Episcleritis & \multicolumn{3}{c}{ Anterior } \\
\cline { 4 - 5 } Posterior & & Diffuse & Nodular & Necrotizing \\
\hline Hoang et al., 1990 [35] & 11 & 0 & $5(45 \%)$ & $3(27 \%)$ & $3(27 \%)$ & 0 \\
Sainz-de-la-Maza et al., 2016 [32] & 13 & 0 & $10(77 \%)$ & 0 & $3(23 \%)$ & 0 \\
Yang et al., 2019 [34] & 10 & 0 & $9(90 \%)$ & $1(10 \%)$ & 0 & 0 \\
Tanaka et al., 2019 [33] & 9 & $1(11 \%)$ & $6(67 \%)$ & 0 & 0 & $2(22 \%)$ \\
\hline
\end{tabular}

\subsection{Uvea}

Uveitis is also a common ocular complication in patients with RPC [2,10,33,34,36,37]; chronic anterior uveitis with hypopyon (Figure 3) is often observed [26,38-41]. In addition, panuveitis with retinitis, including retinal vasculitis and/or hemorrhage, also occurs in RPC $[19,42]$.
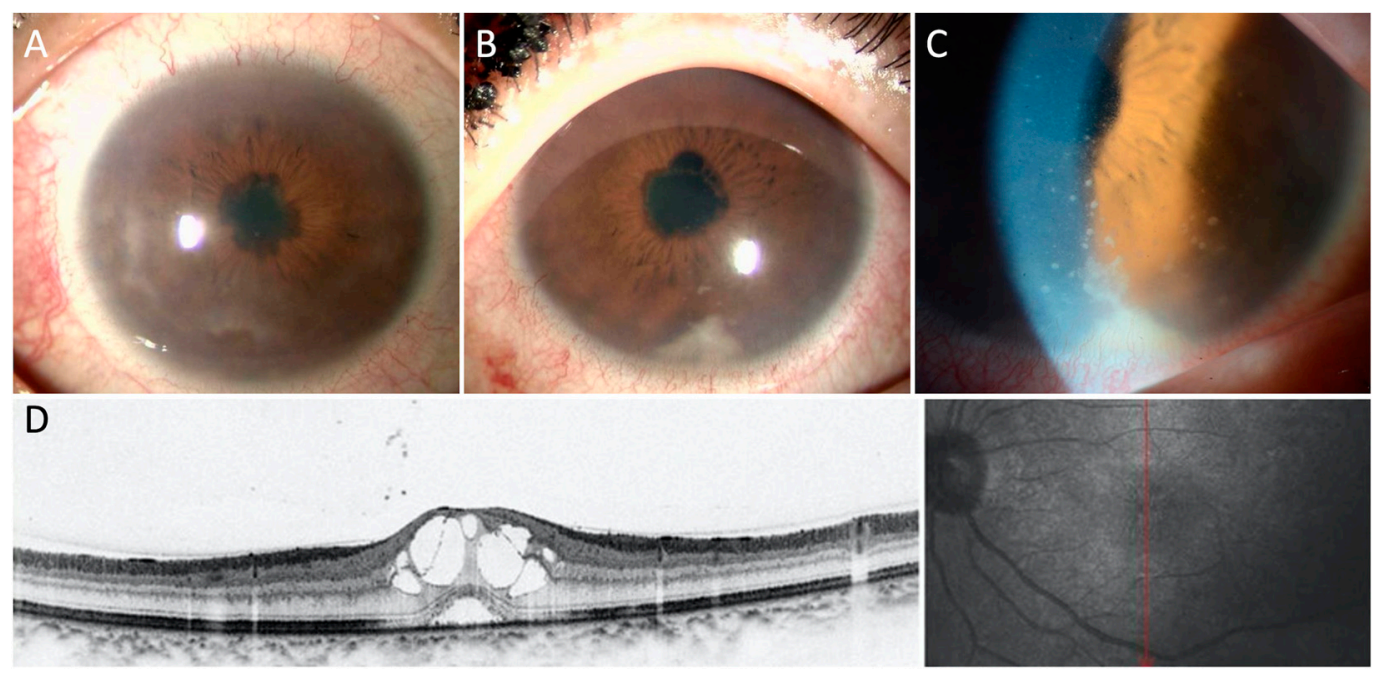

Figure 3. Bilateral anterior uveitis with macular edema in a patient with RPC. Photographs show bilateral anterior uveitis with posterior synechia (A,B). Keratic precipitates and hypopyon are also observed in left eye (B,C). OCT depicts cystoid macular edema (D).

\subsection{Conjunctiva}

Conjunctivitis (Figure 4A) with nonspecific conjunctival redness, irritation, and itching was observed in patients with RPC [2]. Subconjunctival hemorrhage and keratoconjunctivitis sicca have also been observed [10]. Chronic conjunctival inflammation reportedly results in the formation of salmon patch lesions with reactive lymphoid hyperplasia [43]. $\mathrm{Yu}$ et al. demonstrated the pathological examination of conjunctival biopsy [44]. Pathological examination revealed granulomatous obliterative microangiopathy with various inflammatory cells in the substantia fascia, such as eosinophils, plasma cells, lymphocytes, and epithelioid cells. Hoang-Xuan et al. also performed histologic and immunopathologic examinations of ocular biopsy specimens (three conjunctiva and one sclero-cornea) from three patients with RPC. In the conjunctiva, mast cells and chronic inflammatory cells, such as lymphocytes and plasma cells in the substantia propria of all three patients, were observed. Vasculitis was also found in the conjunctiva of two cases and sclera in one case; perivasculitis in the conjunctiva of one patient was observed. Immunofluorescent staining revealed complement (C3) and immunoglobulin ( $\mathrm{IgM}$ and $\mathrm{IgG}$ ) deposition in the vessel walls of conjunctiva [35]. 

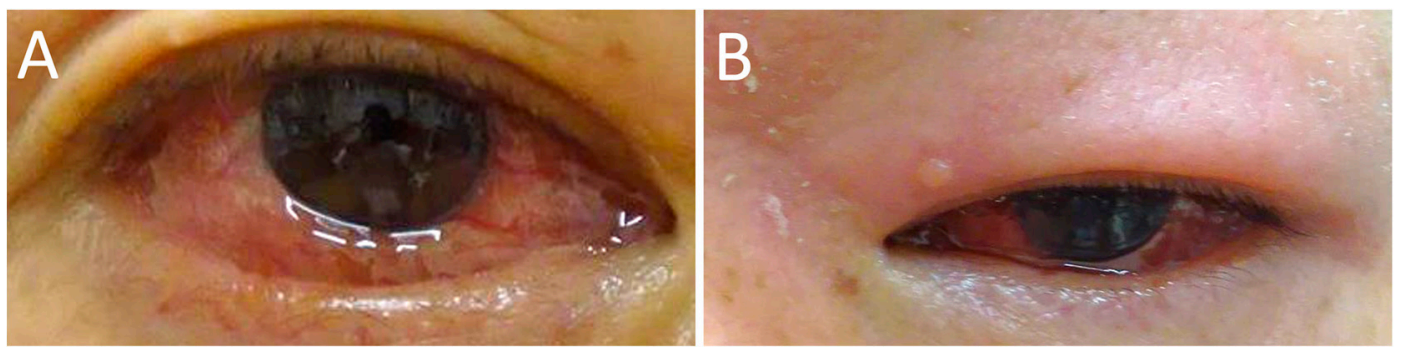

Figure 4. Conjunctivitis and eyelid edema in patients with RPC. Photographs show conjunctival edema and hyperemia (A) and swelling and redness of the upper eyelid (B).

\subsection{Cornea}

In the cornea, peripheral ulcerative keratitis is reportedly a common type of keratitis associated with RPC [10,45-48], which is similar to other connective tissue diseases, such as rheumatoid arthritis [49]. Ulceration sometimes progresses rapidly, resulting in corneal melting and perforation $[45,46]$. Histologic examination of an enucleated eye with a corneal ulcer and perforation demonstrated necrotic corneal stroma and infiltration of inflammatory cells, including polymorphonuclear leukocytes and plasma cells in the peripheral corneal stroma [50]. Corneal infiltrates associated with scleritis are also observed in patients with RPC [10,51]. A case of infective keratitis due to corneal intrastromal infiltrate with hypopyon and a case of atypical crystalline keratopathy in a patient with PRC have been reported $[20,52]$.

\subsection{Eyelid}

Lid edema (Figure 4B) is reportedly observed in approximately $8 \%$ of patients with RPC [10] and occurs in association with orbital inflammation or independently $[10,24,26,29,53]$. Retraction and ptosis of the eyelid have also been observed [10].

\subsection{Lens}

Posterior subcapsular cataracts are frequently observed, presumably due to prolonged intraocular inflammation and/or the consequence of systemic corticosteroid therapy [2,10].

\subsection{Retina}

In a study by Isaak et al., $8 \%$ of RPC patients showed retinopathy consisting of cotton-wool spots (Figure 5A), retinal hemorrhage, and microaneurysms [10]. Retinal vascular occlusion, including central or branched retinal vein occlusion associated with retinal vasculitis, was also observed. Cases with retinal vasculitis, retinal pigment epithelium defects, exudative retinal detachment, and retinal artery occlusion were also reported [19,21,54-56]. Cystoid macular edema (Figure 3D) was observed in patients with uveitis. 

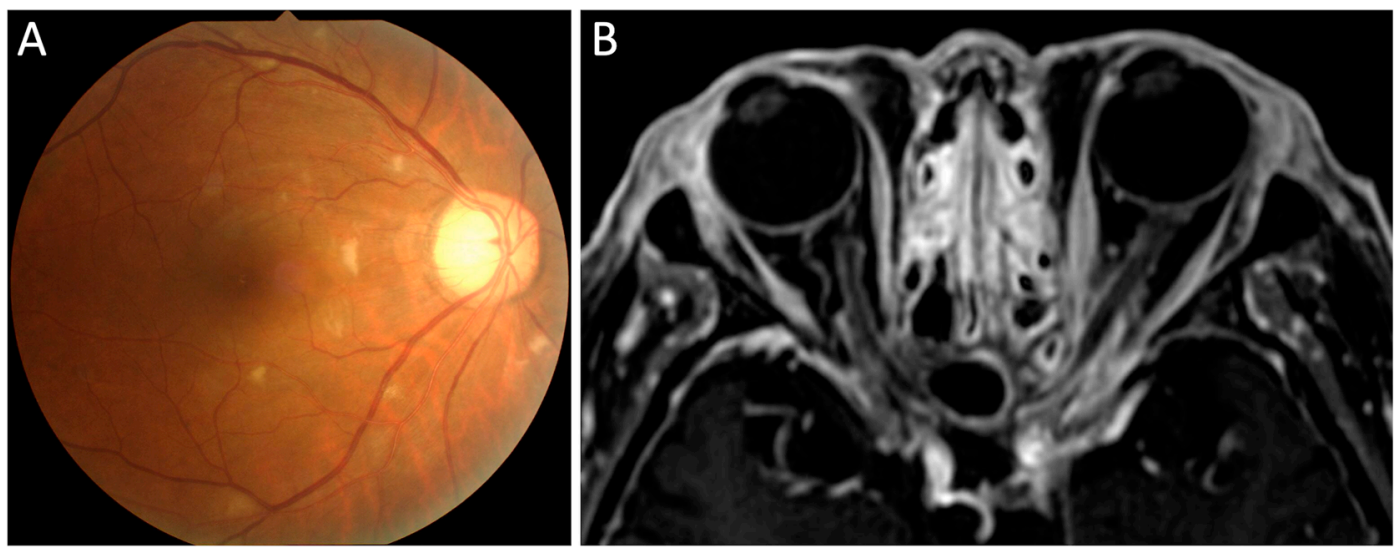

Figure 5. Retinopathy and optic perineuritis in patients with RPC. Fundus photograph shows cotton-wool spots in the retina (A). Gadolinium-enhanced T1-weighted MRI with fat suppression shows the "tram-track" enhancement of the left optic nerve sheath (B).

\subsection{Optic Nerve and Other Cranial Nerve}

Optic neuropathy is a rare ocular complication, although it is the most common cranial nerve disorder associated with RPC. Optic neuropathy includes optic neuritis, papilledema, ischemic optic neuropathy, and optic perineuritis $[10,23,27,57-61]$. Ischemic optic neuropathy may be induced by systemic vasculitis. We have reported two cases of optic perineuritis [23,27]. One patient presented with recurrent optic perineuritis as the first manifestation of RPC [23]. Optic perineuritis (Figure 5B) occurred sequentially after oculomotor nerve palsy, scleritis, and retinitis in another case [27].

Other cranial nerve involvements reportedly include oculomotor and abducens nerve palsies, as well as trigeminal neuralgia $[10,22,26,27,62,63]$. Oculomotor and abducens nerve palsies result in extraocular muscle palsies and can also be the initial manifestation of RPC [22]. Cao et al. analyzed patients with RPC with central nervous system involvement. Of the 25 patients, two had optic nerve involvement, two had oculomotor nerve involvement, one had trigeminal nerve involvement, and one had abducens nerve involvement [12].

\subsection{Orbit and Miscellaneous}

Although it is uncommon, idiopathic orbital inflammation and inflammatory pseudotumor have been observed in RPC, leading to proptosis, periorbital lid edema, eye pain, and restriction of extraocular movements [10,24,25,64-73]. Proptosis with chemosis due to orbital inflammation may be the first manifestation of RPC [25]. Orbital inflammation sometimes affects the cranial nerve and induces oculomotor nerve palsy, optic perineuritis, and tumor invasion of the optic nerve $[65,67,68]$. Although a biopsy may sometimes be difficult due to the lesion location, biopsy of the orbital mass may be helpful to confirm the type of inflammation and exclude malignancy. Tucker et al. examined the histopathology of orbital masses showing reactive lymphoid hyperplasia [43]. Lichauco et al. reported a case of RPC with an orbital mass, and a biopsy of the orbital lesion showed mucosa-associated lymphoid tissue B-cell lymphoma [74]. In addition, a high incidence of hematological malignancies, including leukemia, multiple myeloma, and lymphoma, has been reported in RPC patients [28,75-77]. Therefore, biopsy of the orbital mass should be considered when the effectiveness of corticosteroid treatment is insufficient.

Other reported ocular complications associated with RPC include exophthlmos and dacryocystitis.

\section{Systemic Manifestations}

RPC affects various tissues and manifests with various symptoms. The systemic symptoms of RPC other than ocular symptoms are listed in Table 5. Auricular chondritis is the 
most common manifestation of RPC, causing bilateral or unilateral auricular pain, redness, and swelling. While approximately $60-90 \%$ of RPC patients experience auricular chondritis during the course of the disease (Table 6 ), only $40 \%$ of patients present ear involvement initially $[4,10,14]$. Prolonged and repeated inflammation of the ear pinna destroys the pinna, resulting in floppy pinna or cauliflower ear [78]. Therefore, ophthalmologists should pay attention to ear swelling and redness in patients with ocular inflammation at the time of the initial examination and during the course of the disease.

RPC is reportedly associated with many other autoimmune conditions, including systemic vasculitis, rheumatoid arthritis, systemic lupus erythematosus, Behçet's syndrome, spondylarthritis, and inflammatory bowel disease. In addition, cases of RPC with hematologic diseases, such as myelodysplastic syndromes, lymphoma, or leukemia, have been reported $[79,80]$.

Table 5. Clinical systemic manifestation of RPC.

\begin{tabular}{|c|c|}
\hline Involvement & Symptoms/Manifestations \\
\hline Ear & $\begin{array}{l}\text { Auricular chondritis, hearing loss, tinnitus, serous otitis media, } \\
\text { Vestibular dysfunction (vertigo, ataxia, nausea, vomiting) }\end{array}$ \\
\hline Nose & Nasal chondritis, saddle nose deformity, rhinorrhea, epistaxis \\
\hline Respiratory & $\begin{array}{l}\text { Hoarseness, cough, aphonia, dyspnea, wheezing inspiratory stridor, } \\
\text { Laryngotracheal stricture and collapse }\end{array}$ \\
\hline Renal & $\begin{array}{c}\text { Elevation of creatinine, microhematuria, proteinuria, necrotizing glomerulonephritis, } \\
\text { Glomerulosclerosis, IgA nephropathy, tubulointerstitial nephritis }\end{array}$ \\
\hline Musculoskeletal & Arthritis, costochondral cartilage tenderness, flail chest, dislocation \\
\hline Cardiovascular & $\begin{array}{l}\text { Valvular heart disease, aneurysm, pericarditis, vasculitis, } \\
\text { Coronary heart disease, tachycardia, atrioventricular block }\end{array}$ \\
\hline Skin & $\begin{array}{l}\text { Urticaria, purpura, oral aphthosis, angioedema, erythema multiforme, } \\
\text { Erythema nodosum, livedo reticularis, panniculitis, superficial phlebitis, dermatomyositis }\end{array}$ \\
\hline Neurologic & $\begin{array}{l}\text { Headaches, cranial neuropathies, encephalopathies, } \\
\text { Seizures, hemiplegia, ataxia }\end{array}$ \\
\hline General & Fever, Fatigue, weight loss, night sweat, swelling of lymph nodes \\
\hline
\end{tabular}

Table 6. Incidence of major systemic manifestations of RPC in large case series.

\begin{tabular}{|c|c|c|c|c|c|c|c|}
\hline Symptoms & $\begin{array}{l}\text { Zhang et al., } \\
2021 \text { [14] }\end{array}$ & $\begin{array}{c}\text { Dion et al., } \\
2016 \text { [16] }\end{array}$ & $\begin{array}{l}\text { Lin et al., } \\
2016 \text { [8] }\end{array}$ & $\begin{array}{l}\text { Oka et al., } \\
2014 \text { [17] }\end{array}$ & $\begin{array}{c}\text { Zeuner et al., } \\
1997 \text { [18] }\end{array}$ & $\begin{array}{c}\text { Michet et al., } \\
1986 \text { [4] }\end{array}$ & $\begin{array}{c}\text { McAdam et al., } \\
1976[2]\end{array}$ \\
\hline Number of Patients & 126 & 142 & 158 & 239 & 62 & 112 & 23 \\
\hline $\begin{array}{l}\text { Auricular } \\
\text { chondritis }\end{array}$ & $60 \%$ & $89 \%$ & $68 \%$ & $78 \%$ & $94 \%$ & $85 \%$ & $91 \%$ \\
\hline Hearing loss & $12 \%$ & $27 \%$ & $25 \%$ & $22 \%$ & $19 \%$ & $26 \%$ & $61 \%$ \\
\hline $\begin{array}{l}\text { Vestibular } \\
\text { dysfunction }\end{array}$ & NA & $20 \%$ & $18 \%$ & $27 \%$ & $23 \%$ & $13 \%$ & $57 \%$ \\
\hline Nasal chondritis & $18 \%$ & $63 \%$ & $54 \%$ & $39 \%$ & $57 \%$ & $54 \%$ & $70 \%$ \\
\hline Laryngotracheal & $48 \%$ & $50 \%$ & $69 \%$ & $50 \%$ & $31 \%$ & $48 \%$ & $48 \%$ \\
\hline Renal involvement & $0 \%$ & $0 \%$ & $2.5 \%$ & $6.7 \%$ & $6.5 \%$ & $14 \%$ & NA \\
\hline Arthritis & $18 \%$ & $69 \%$ & $56 \%$ & $39 \%$ & $53 \%$ & $52 \%$ & $83 \%$ \\
\hline Valvulopathy & $0.8 \%$ & $22 \%$ & $1.9 \%$ & $2.1 \%$ & $0 \%$ & $6.3 \%$ & $17 \%$ \\
\hline Skin involvement & $1.6 \%$ & $28 \%$ & $46 \%$ & $13 \%$ & $24 \%$ & $28 \%$ & $39 \%$ \\
\hline CNS involvement & $4.8 \%$ & $7.7 \%$ & $12 \%$ & $9.6 \%$ & $9.7 \%$ & NA & NA \\
\hline
\end{tabular}




\section{Laboratory Findings and Diagnosis}

Diagnosis of RPC is determined by the clinical manifestations and/or pathologic examination according to the diagnostic criteria. To date, several clinical diagnostic criteria have been proposed. In 1976, McAdam et al. first proposed the diagnostic criteria of RPC [2]: three or more of six clinical features, including auricular chondritis, nonerosive inflammatory polyarthritis, nasal chondritis, respiratory tract chondritis, audio vestibular damage, and ocular inflammation, are needed for diagnosis. Damiani and Levine [3] modified McAdam's criteria by adding histological confirmation and response to treatment. Michet et al. [4] also proposed diagnostic criteria for clinical symptoms without histological confirmation.

There is no specific laboratory testing for RPC; C-reactive protein levels and erythrocyte sedimentation rate (ESR) are usually elevated, reflecting systemic inflammatory responses. Although the specificity is not very high, anti-type II collagen antibody is detected in the acute phase of RPC, and the serum level of this antibody reportedly correlates with disease severity [81]. Increased levels of anti-matrilin 1 antibody [82] and cartilage oligomeric matrix protein [83] are also reportedly increased in the acute phase of RPC.

Imaging tests, such as computed tomography (CT), magnetic resonance imaging (MRI), 18F-fluorodeoxyglucose-positron emission tomography/CT (FDG-PET/CT), and color Doppler ultrasonography, are useful tools for estimating local inflammation and diagnosing RPC. CT is primarily used for evaluation from the larynx to the subsegmental bronchi. Chest CTs can show airways thickening without a posterior membranous wall and narrowing because of cartilaginous destruction. In particular, expiratory CTs have shown air trapping in the early stages [84]. FDG-PET/CT is an effective imaging modality for detecting all RPC lesions, including auricular, nasal cartilage, larynx and trachea, bronchial, costal, and joints chondritis (Figure 6); FDG-PET/CT can lead to early diagnosis and the evaluation of the disease activity and therapeutic effects [85].
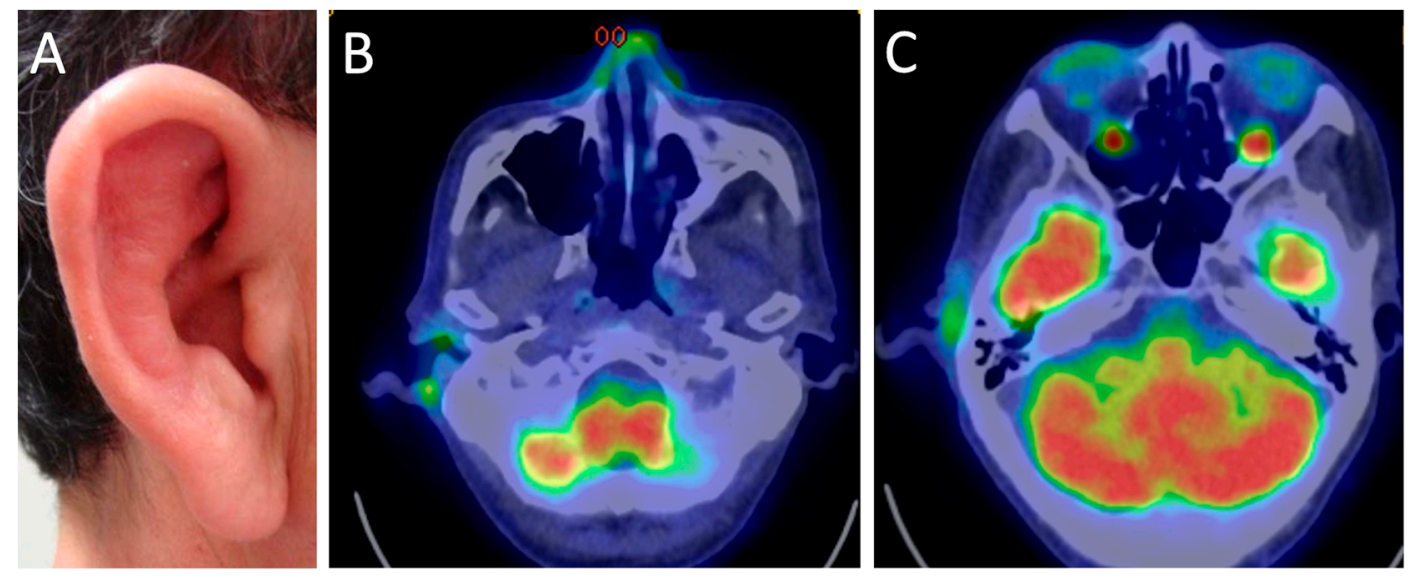

Figure 6. PET/CT images of a patient with right auricular chondritis, nasal chondritis, and bilateral scleritis due to RPC. The right pinna is red and swollen (A), and FDG-PET/CT shows high signal intensities (green) in the right auricle, nasal cartilage (B), and bilateral sclera (C).

MRI is also a useful tool for evaluating articular and ear involvement. Perichondrium, chondroepiphysis, and acrophsis are fluid-sensitive sequences of hyperintensity and enhancement after gadolinium administration. RPC with inner-ear involvement shows enhancement of the vestibular area [86]. Diffusion-weighted magnetic resonance imaging can also detect auricular inflammation as a hyperintensity signal in patients with RPC (Figure 7) [87]. 
The clinical implications of ultrasonography of the ear pinna in the diagnosis and monitoring of disease activity of RPC have been reported (Figure 7) [88]. Color Doppler ultrasonography is a convenient, rapid, and noninvasive tool for the estimation of tissue inflammation and blood flow. We have also demonstrated the usefulness of differential diagnosis of giant cell arteritis in patients with ischemic optic neuropathy [89,90]. Therefore, color Doppler ultrasonography of the ear pinna and temporal arteries may be useful for the differential diagnosis of RPC and arteritic ischemic optic neuropathy.
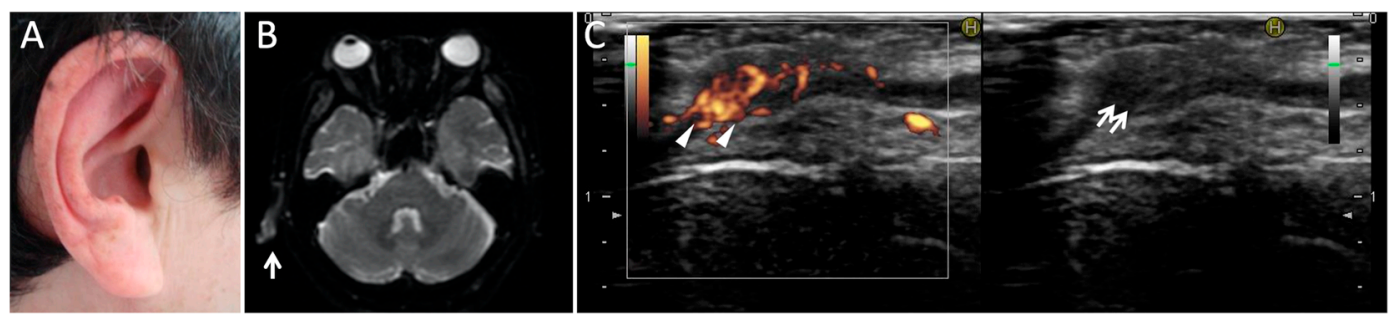

Figure 7. Magnetic resonance imaging and ultrasonography of auricular chondritis in a patient with optic perineuritis due to RPC. The right pinna is red and swollen (A) and diffusion-weighted magnetic resonance imaging (B) shows signal hyperintensity of the right auricle (arrow). Ultrasonography $(\mathbf{C})$ reveals a high-power Doppler signal surrounding the cartilage (arrowheads) and swollen auricular cartilage (arrows).

\section{Treatment}

Although there are several review articles about the treatment of RPC [80,91,92], there has been no randomized clinical trial or evidence-based guideline for the treatment of RPC due to the rarity of the disease. In general, topical treatment alone for ocular inflammation in RPC is insufficient in most cases, and systemic treatment with a rheumatologist may be needed. Various anti-inflammatory therapeutic modalities have been reported, including nonsteroidal anti-inflammatory drugs (NSAIDs), corticosteroids, immunosuppressants, and biologics, depending on the severity of the disease. In mild cases, NSAIDs, dapsone, and colchicine are used [79,80,93,94]. Systemic glucocorticoids are needed for severe cases, including ocular inflammation, and usually require long-term oral administration to prevent relapse. Immunosuppressants, including cyclophosphamide, methotrexate, azathioprine, and cyclosporine, are used as second-line options for steroid-intolerant patients or patients needing steroid-sparing $[6,9,81]$. Recently, various biologics, including infliximab, etanercept, adalimumab, rituximab, anakinra, tocilizumab, and abatacept, have reportedly been used [91,92,95-97].

Refractory scleritis associated with RPC has been successfully treated with immunosuppressants (cyclosporine, azathioprine, and cyclophosphamide) [35,98,99], infliximab (anti-tumor necrosis factor $\alpha$ antibody) [100,101], or tocilizumab (anti-interleukin- 6 receptor antibody) [102,103], in addition to corticosteroids. Surgical interventions may also be required for complications of ocular inflammation, such as cataract, secondary glaucoma, or perforation of the cornea $[47,104,105]$.

\section{Conclusions}

Although RPC is a potentially fatal and sight-threatening disease, the rarity of the disease, protean clinical presentations, and wax-and-wane disease courses may lead to missed or delayed diagnosis of RPC $[8,9,14]$. Early diagnosis of RPC and prompt treatment are critical to prevent RPC-associated complications and death and to improve prognosis. Ocular manifestations also vary, as described in this review. Given the high prevalence of ocular involvement in RPC, to avoid misdiagnosis, physicians should be suspicious of RPC when they see patients with recurrent ocular inflammatory conditions with various systemic symptoms. 
Author Contributions: Conceptualization, K.F.; writing-original draft preparation, K.F.; writingreview and editing, T.M., I.N., T.K., Y.M. and Y.T. All authors have read and agreed to the published version of the manuscript.

Funding: This research received no external funding.

Institutional Review Board Statement: Not applicable.

Informed Consent Statement: Given that this was a review article, patient consent was waived.

Data Availability Statement: Not applicable.

Conflicts of Interest: The authors declare no conflict of interest.

\section{References}

1. Jaksch-Wartenhorst, R. Polychondropathia. Arch. Inn. Med. 1923, 6, 93-100.

2. McAdam, L.P.; A O'Hanlan, M.; Bluestone, R.; Pearson, C.M. Relapsing polychondritis: Prospective study of 23 patients and a review of the literature. Medicine 1976, 55, 193-215. [CrossRef]

3. Damiani, J.M.; Levine, H.L. Relapsing polychondritis-Report of ten cases. Laryngoscope 1979, 89 Pt 1, 929-946. [CrossRef]

4. Michet, C.J., Jr.; McKenna, C.H.; Luthra, H.S.; O'Fallon, W.M. Relapsing polychondritis. Survival and predictive role of early disease manifestations. Ann. Intern. Med. 1986, 104, 74-78. [CrossRef]

5. Kent, P.D.; Michet, C.J., Jr.; Luthra, H.S. Relapsing polychondritis. Curr. Opin. Rheumatol. 2004, 16, 56-61. [CrossRef]

6. Hazra, N.; Dregan, A.; Charlton, J.; Gulliford, M.; D'Cruz, D.P. Incidence and mortality of relapsing polychondritis in the UK: A population-based cohort study. Rheumatology 2015, 54, 2181-2187. [CrossRef]

7. Mathew, S.D.; Battafarano, D.F.; Morris, M.J. Relapsing Polychondritis in the Department of Defense Population and Review of the Literature. Semin. Arthritis Rheum. 2012, 42, 70-83. [CrossRef]

8. Lin, D.-F.; Yang, W.; Zhang, P.-P.; Lv, Q.; Jin, O.; Gu, J.-R. Clinical and prognostic characteristics of 158 cases of relapsing polychondritis in China and review of the literature. Rheumatol. Int. 2016, 36, 1003-1009. [CrossRef]

9. Trentham, D.E.; Le, C.H. Relapsing polychondritis. Ann. Intern. Med. 1998, 129, 114-122. [CrossRef]

10. Isaak, B.L.; Liesegang, T.; Michet, C.J. Ocular and Systemic Findings in Relapsing Polychondritis. Ophthalmology 1986, 93, 681-689. [CrossRef]

11. Yoo, J.H.; Chodosh, J.; Dana, R. Relapsing Polychondritis: Systemic and Ocular Manifestations, Differential Diagnosis, Management, and Prognosis. Semin. Ophthalmol. 2011, 26, 261-269. [CrossRef]

12. Cao, X.; Zhu, L.; Li, H.; Jiang, L.; Xu, D.; Zhao, J.; Zhou, J.; Zhang, F.; Hou, Y.; Zeng, X. Comparison of relapsing polychondritis patients with and without central nervous system involvement: A retrospective study of 181 patients. Int. J. Immunopathol. Pharmacol. 2021, 35. [CrossRef]

13. Chen, N.; Zheng, Y. Characteristics and Clinical Outcome of 295 Patients with Relapsing Polychondritis. J. Rheumatol. 2021. [CrossRef]

14. Zhang, L.; Yun, S.; Wu, T.; He, Y.; Guo, J.; Han, L.; Lu, J.; Liu, X.; Yang, R.; Zhang, S.; et al. Clinical patterns and the evolution of relapsing polychondritis based on organ involvement: A Chinese retrospective cohort study. Orphanet J. Rare Dis. 2021, 16, 225. [CrossRef]

15. Ferrada, M.A.; Grayson, P.C.; Banerjee, S.; Sikora, K.A.; Colbert, R.A.; Sinaii, N.; Katz, J.D. Patient Perception of Disease-Related Symptoms and Complications in Relapsing Polychondritis. Arthritis Rheum. 2018, 70, 1124-1131. [CrossRef]

16. Dion, J.; Costedoat-Chalumeau, N.; Sène, D.; Cohen-Bittan, J.; Leroux, G.; Dion, C.; Francès, C.; Piette, J.-C. Relapsing Polychondritis Can Be Characterized by Three Different Clinical Phenotypes: Analysis of a Recent Series of 142 Patients. Arthritis Rheumatol. 2016, 68, 2992-3001. [CrossRef]

17. Oka, H.; Yamano, Y.; Shimizu, J.; Yudoh, K.; Suzuki, N. A large-scale survey of patients with relapsing polychondritis in Japan. Inflamm. Regen. 2014, 34, 149-156. [CrossRef]

18. Zeuner, M.; Straub, R.H.; Rauh, G.; Albert, E.D.; Schölmerich, J.; Lang, B. Relapsing polychondritis: Clinical and immunogenetic analysis of 62 patients. J. Rheumatol. 1997, 24, 96-101.

19. Hosseini, S.M.; Shirzad, S.; Ghasemi, M. Bilateral Panuveitis and Keratitis as First Presentation of Relapsing Polychondritis. Ocul. Immunol. Inflamm. 2018, 27, 1267-1269. [CrossRef]

20. Sallam, A.; Islam, T.; Parmar, D.N. Keratouveitis as a First Presentation of Relapsing Polychondritis. Case Rep. Med. 2010, 2010, 176514. [CrossRef]

21. Paroli, M.P.; Priori, R.; Spinucci, G.; Abicca, I.; Valesini, G. Uveitis with retinal occlusive vasculitis and sensorineural hypoacusia as first symptoms of relapsing polychondritis. Clin. Exp. Rheumatol. 2012, 30, S101-S103.

22. Akiyama, M.; Kaneko, Y.; Hanaoka, H.; Kuwana, M.; Takeuchi, T. Polychondritis presenting with oculomotor and abducens nerve palsies as the initial manifestation. Mod. Rheumatol. 2014, 26, 790-793. [CrossRef] [PubMed]

23. Miura, Y.; Fukuda, K.; Taniguchi, Y.; Komori, M.; Fukushima, A. Recurrent Optic Perineuritis as the First Manifestation of Relapsing Polychondritis. J. Neuro-Ophthalmol. 2019, 39, 513-514. [CrossRef] [PubMed] 
24. Sheikh, A.; Rodgers, R. Fulminant orbital inflammatory syndrome in a patient with relapsing polychondritis: Case report and review of the literature. Orbit 2021, 40, 252-254. [CrossRef]

25. Teo, L.; Choo, C.T. Orbital Inflammatory Disease in Relapsing Polychondritis. Orbit 2014, 33, 298-301. [CrossRef] [PubMed]

26. Fukuda, K.; Kishimoto, T.; Fukushima, A. Miscellaneous Ocular Symptoms in a Case of Relapsing Polychondritis. Ocul. Immunol. Inflamm. 2021, 29, 352-354. [CrossRef] [PubMed]

27. Ikeda, T.; Yoshida, T.; Yamamoto, H.; Hashida, M.; Urabe, K.; Sotozono, C.; Fukuda, K. Sequential Involvement of Oculomotor Nerve and Optic Nerve Sheath in Relapsing Polychondritis. J. Neuro-Ophthalmol. 2021. Published Ahead-of-Print. [CrossRef]

28. Chuah, T.; Lui, N. Relapsing polychondritis in Singapore: A case series and review of literature. Singap. Med. J. 2017, 58, 201-205. [CrossRef] [PubMed]

29. Oshitari, T.; Furuya, N.; Yotsukura, J.; Baba, T.; Yamamoto, S. Relapsing polychondritis with different types of ocular inflammations. Int. Med. Case Rep. J. 2015, 8, 193-197. [CrossRef]

30. Loeffler, K.U.; McLean, I.W. Bilateral necrotizing scleritis and blindness in the myelodysplastic syndrome presumably due to relapsing polychondritis. Acta Ophthalmol. Scand. 2000, 78, 228-231. [CrossRef]

31. Meel, R.; Das, D.; Bhadu, D.; Sen, S.; Kishor, K.; Pushker, N. Bilateral Nodular Episcleritis: A Rare Presentation of Relapsing Polychondritis. Ophthalmic Plast. Reconstr. Surg. 2021, 37, e103-e105. [CrossRef]

32. Sainz-De-La-Maza, M.; Molina, N.; Gonzalez-Gonzalez, L.A.; Doctor, P.P.; Tauber, J.; Foster, C.S. Scleritis associated with relapsing polychondritis. Br. J. Ophthalmol. 2016, 100, 1290-1294. [CrossRef] [PubMed]

33. Tanaka, R.; Kaburaki, T.; Nakahara, H.; Komae, K. Ocular inflammation associated with relapsing polychondritis in Japanese patients: A review of 11 patients. Int. Ophthalmol. 2019, 39, 2649-2659. [CrossRef] [PubMed]

34. Yang, P.; Yuan, W.; Du, L.; Zhou, Q.; Wang, C.; Ye, Z.; Kijlstra, A. Clinical features of Chinese patients with relapsing polychondritis. Br. J. Ophthalmol. 2018, 103, 1129-1132. [CrossRef]

35. Hoang-Xaun, T.; Foster, C.S.; Rice, B.A. Scleritis in relapsing polychondritis. Response to therapy. Ophthalmology 1990, 97, 892-898. [CrossRef]

36. Wei, Y.; Chi, Y.; Fang, Y.; Wu, D.; Qiao, R. Chronic Anterior Uveitis Associated with Relapsing Polychondritis: A Case Report. Ocul. Immunol. Inflamm. 2018, 28, 67-69. [CrossRef] [PubMed]

37. Hasanreisoğlu, M.; Özdemir, H.B.; Yaylacıoğlu, F.; Ertop, M.; Aktaş, Z. Bilateral Anterior Uveitis Revealing Relapsing Polychondritis. Turk. J. Ophthalmol. 2019, 49, 99-101. [CrossRef]

38. Anderson, N.G.; Garcia-Valenzuela, E.; Martin, D.F. Hypopyon uveitis and relapsing polychondritis*1A report of 2 patients and review of autoimmune hypopyon uveitis. Ophthalmology 2004, 111, 1251-1254. [CrossRef]

39. Zorlutuna Kaymak, N.; Oklar, M.; Tanyildiz, B.; Tezcan, M.E.; ŞİmŞek, Ş. A Rare Cause of Hypopyon Anterior Uveitis: Relapsing Polychondritis. Arch. Rheumatol. 2020, 35, 142-145. [CrossRef]

40. Genevois, O.; Calenda, E.; Nasser, Z.; Benzerroug, M.; Gardea, E.; Muraine, M. Hypopyon uveitis (without scleritis) a manifestation symptom of relapsing polychondritis. Ann. Ophthalmol. 2010, 41, 208-211.

41. Salah, R.B.; Frikha, F.; Hentati, Y.; Kallel, S.; Ghorbel, A.; Mnif, Z.; Bahloul, Z. Recurrent anterior uveitis with hypopyon revealing relapsing polychondritis. Intern. Med. 2012, 51, 3173-3176. [CrossRef] [PubMed]

42. Masuda, N.; Nishikawa, R.; Ueda, T.; Ogata, N. Severe panuveitis with relapsing polychondritis. Am. J. Ophthalmol. Case Rep. 2018, 11, 3-5. [CrossRef] [PubMed]

43. Tucker, S.M.; Linberg, J.V.; Doshi, H.M. Relapsing polychondritis, another cause for a "salmon patch". Ann. Ophthalmol. 1993, 25, 389-391. [PubMed]

44. Yu, E.N.; Jurkunas, U.; Rubin, P.A.; Baltatzis, S.; Foster, C.S. Obliterative Microangiopathy Presenting as Chronic Conjunctivitis in a Patient With Relapsing Polychondritis. Cornea 2006, 25, 621-622. [CrossRef] [PubMed]

45. Lai, T.H.T.; Far, N.; Young, A.L.; Jhanji, V. Rapid corneal thinning and perforated ulcerative keratitis in a patient with relapsing polychondritis. Eye Vision 2017, 4, 8. [CrossRef] [PubMed]

46. Matoba, A.; Plager, S.; Barber, J.; McCulley, J.P. Keratitis in relapsing polychondritis. Ann. Ophthalmol. 1984, 16, 367-370.

47. Kato, T.; Yamaguchi, T.; Hamanaka, T.; Kanai, A. Corneal marginal ulcer in relapsing polychondritis: Treatment with keratoepithelioplasty. Ophthalmic Surg. Lasers 1998, 29, 767-769. [CrossRef]

48. Michelson, J.B. Melting corneas with collapsing nose. Surv. Ophthalmol. 1984, 29, 148-154. [CrossRef]

49. Messmer, E.M.; Foster, C. Vasculitic Peripheral Ulcerative Keratitis. Surv. Ophthalmol. 1999, 43, 379-396. [CrossRef]

50. Barth, W.F.; Berson, E.L. Relapsing Polychondritis, Rheumatoid Arthritis and Blindness. Am. J. Ophthalmol. 1968, 66, 890-896. [CrossRef]

51. Motozawa, N.; Nakamura, T.; Takagi, S.; Fujihara, M.; Hirami, Y.; Ishida, K.; Sotozono, C.; Kurimoto, Y. Unique circumferential peripheral keratitis in relapsing polychondritis: A case report. Medicine 2017, 96, e7951. [CrossRef]

52. Wang, K.; Gonzales, J.; Pawar, V.; Cheewaruangroj, N.; Seitzman, G.D. Multimodal Imaging Report of Crystalline Keratopathy in Relapsing Polychondritis. Cornea 2019, 38, 918-920. [CrossRef] [PubMed]

53. Khan, J.H.; Ahmed, I. A case of relapsing polychondritis involving the tragal and the conchal bowl areas with sparing of the helix and the antihelix. J. Am. Acad. Dermatol. 1999, 41, 299-302. [CrossRef]

54. Ridgway, H.B.; Hansotia, P.L.; Schorr, W.F. Relapsing polychondritis: Unusual neurological findings and therapeutic efficacy of dapsone. Arch. Dermatol. 1979, 115, 43-45. [CrossRef] [PubMed] 
55. Hemry, D.A.; Moss, A.J.; Jacox, R.F. Relapsing Polychondritis, a “Floppy" Mitral Valve, and Migratory Polytendonitis. Ann. Intern. Med. 1972, 77, 576. [CrossRef]

56. Magargal, L.E.; Donoso, L.A.; Goldberg, R.E.; Gonder, J.; Brodsky, I. Ocular manifestations of relapsing polychondritis. Retin. 1981, 1, 96-99. [CrossRef]

57. Hirunwiwatkul, P.; Trobe, J. Optic Neuropathy Associated with Periostitis in Relapsing Polychondritis. J. Neuro-Ophthalmol. 2007, 27, 16-21. [CrossRef]

58. Massry, G.G.; Chung, S.M.; Selhorst, J.B. Optic neuropathy, headache, and diplopia with MRI suggestive of cerebral arteritis in relapsing polychondritis. J. Neuro-Ophthalmol. 1995, 15, 171-175. [CrossRef]

59. Killian, P.J.; Susac, J.; Lawless, O.J. Optic neuropathy in relapsing polychondritis. JAMA 1978, 239, 49-50. [CrossRef]

60. Herrero-Morant, A.; Álvarez-Reguera, C.; Martín-Varillas, J.L.; Calvo-Río, V.; Casado, A.; Prieto-Peña, D.; Atienza-Mateo, B.; Maiz-Alonso, O.; Blanco, A.; Vicente, E.; et al. Biologic Therapy in Refractory Non-Multiple Sclerosis Optic Neuritis Isolated or Associated to Immune-Mediated Inflammatory Diseases. A Multicenter Study. J. Clin. Med. 2020, 9, 2608. [CrossRef]

61. Pazirandeh, M.; Ziran, B.H.; Khandelwal, B.K.; Reynolds, T.L.; A Khan, M. Relapsing polychondritis and spondyloarthropathies. J. Rheumatol. 1988, 15, 630-632. [PubMed]

62. Pamuk, O.N.; Harmandar, F.; Cakir, N. The development of trigeminal neuralgia related to auricular chondritis in a patient with rheumatoid arthritis-relapsing polychondritis and its treatment with etanercept. Description of the first case. Clin. Exp. Rheumatol. 2009, 27, 128-129.

63. Rucker, C.W.; Ferguson, R.H. Ocular Manifesations of Relapsing Polychondritis. Arch. Ophthalmol. 1965, 73, 46-48. [CrossRef]

64. Haldar, S.; Jackson, D.; Magliano, M.; Scawn, R. Relapsing periorbital polychondritis: A great ophthalmic masquerader. Can. J. Ophthalmol. 2018, 54, e16-e18. [CrossRef] [PubMed]

65. Eun, Y.H.; Seok, H.; Shin, I.S.; Lee, S.-E.; Lee, Y.-B.; Lee, J. Relapsing polychondritis presenting with inflammatory pseudotumor. Korean J. Intern. Med. 2016, 31, 1003-1005. [CrossRef] [PubMed]

66. Moore, G.H.; Rootman, D.B.; Roybal, C.N.; Goldberg, R.A. Orbital Relapsing Polychondritis: A Unique Presentation, Complication, and Treatment. Ophthalmic Plast Reconstr. Surg. 2016, 32, e34-6. [CrossRef] [PubMed]

67. Wang, C.-R.; Hsu, S.-M.; Chen, Y.-C.; Ho, C.-L.; Fang, S.-Y. Idiopathic Sclerosing Orbital Inflammation in a Relapsing Polychondritis Patient with Impaired Vision. JCR: J. Clin. Rheumatol. 2019, 25, e82-e83. [CrossRef]

68. Kim, J.-S.; Kim, N. Visual loss in relapsing polychondritis: Rapid progression of orbital inflammation. Clin. Exp. Ophthalmol. 2017, 45, 930-932. [CrossRef]

69. Mariani, A.F.; Malik, A.I.; Chevez-Barrios, P.; Smith, S.V.; Lee, A.G. Idiopathic Orbital Inflammation Associated With Relapsing Polychondritis. Ophthalmic Plast. Reconstr. Surg. 2017, 33 (Suppl. S1), S167-S168. [CrossRef]

70. Crovato, F.; Nigro, A.; De Marchi, R.; Rebora, A. Exophthalmos in relapsing polychondritis. Arch. Dermatol. 1980, 116, 383-384. [CrossRef] [PubMed]

71. Rucker, C.W.; Ferguson, R.H. Ocular manifestations of relapsing polychondritis. Trans. Am. Ophthalmol. Soc. 1964, 62, 167-172 [CrossRef]

72. A McKay, D.; Watson, P.G.; Lyne, A.J. Relapsing polychondritis and eye disease. Br. J. Ophthalmol. 1974, 58, 600-605. [CrossRef] [PubMed]

73. Kaye, R.L.; Sones, D.A. Relapsing Polychondritis. Clinical and Pathologic Features in Fourteen Cases. Ann. Intern. Med. 1964, 60, 653-664. [CrossRef]

74. Lichauco, J.J.; Lauer, S.; Shigemitsu, H.H.; Bello, J.A.; Bhattacharyya, P.K.; Barland, P.; Putterman, C. Orbital mucosa-associated lymphoid tissue (MALT)-type lymphoma in a patient with relapsing polychondritis. Arthritis Rheum. 2001, 44, 1713-1715. [CrossRef]

75. Miller, S.B.; Donlan, C.J.; Roth, S.B. Hodgkin's disease presenting as relapsing polychondritis. A previously undescribed association. Arthritis Rheum. 1974, 17, 598-602. [CrossRef] [PubMed]

76. Bochtler, T.; Hensel, M.; Lorenz, H.-M.; Ho, A.D.; Mahlknecht, U. Chronic lymphocytic leukaemia and concomitant relapsing polychondritis: A report on one treatment for the combined manifestation of two diseases. Rheumatology 2005, 44, 1199. [CrossRef] [PubMed]

77. Yanagi, T.; Matsumura, T.; Kamekura, R.; Sasaki, N.; Hashino, S. Relapsing polychondritis and malignant lymphoma: Is polychondritis paraneoplastic? Arch. Dermatol. 2007, 143, 89-90. [CrossRef] [PubMed]

78. Bachor, E.; Blevins, N.H.; Karmody, C.; Kühnel, T. Otologic manifestations of relapsing polychondritis: Review of literature and report of nine cases. Auris Nasus Larynx 2006, 33, 135-141. [CrossRef] [PubMed]

79. Schumacher, S.; Pieringer, H. Relapsing polychondritis: A chameleon among orphan diseases Rezidivierende Polychondritis: Ein Chamäleon unter den seltenen Erkrankungen. Wien. Med. Wochenschr. 2017, 167, 96-233. [CrossRef] [PubMed]

80. Vitale, A.; Sota, J.; Rigante, D.; Lopalco, G.; Molinaro, F.; Messina, M.; Iannone, F.; Cantarini, L. Relapsing Polychondritis: An Update on Pathogenesis, Clinical Features, Diagnostic Tools, and Therapeutic Perspectives. Curr. Rheumatol. Rep. $2016,18,3$. [CrossRef]

81. Letko, E.; Zafirakis, P.; Baltatzis, S.; Voudouri, A.; Livir-Rallatos, C.; Foster, C. Relapsing polychondritis: A clinical review. Semin. Arthritis Rheum. 2002, 31, 384-395. [CrossRef] [PubMed] 
82. Hansson, A.-S.; Piette, J.-C.; Burkhardt, H.; Holmdahl, R. The occurrence of autoantibodies to matrilin 1 reflects a tissue-specific response to cartilage of the respiratory tract in patients with relapsing polychondritis. Arthritis Rheum. 2001, 44, $2402-2412$. [CrossRef]

83. Lekpa, F.K.; Piette, J.C.; Bastuji-Garin, S.; Kraus, V.B.; Stabler, T.V.; Poole, A.R.; Marini-Portugal, A.; Chevalier, X. Serum cartilage oligomeric matrix protein (COMP) level is a marker of disease activity in relapsing polychondritis. Clin. Exp. Rheumatol. 2010, 28, 553-555.

84. Lee, K.; Ernst, A.; Trentham, D.E.; Lunn, W.; Feller-Kopman, D.J.; Boiselle, P.M. Relapsing Polychondritis: Prevalence of Expiratory CT Airway Abnormalities 1. Radiology 2006, 240, 565-573. [CrossRef]

85. Kubota, K.; Yamashita, H.; Mimori, A. Clinical Value of FDG-PET/CT for the Evaluation of Rheumatic Diseases: Rheumatoid Arthritis, Polymyalgia Rheumatica, and Relapsing Polychondritis. Semin. Nucl. Med. 2017, 47, 408-424. [CrossRef]

86. Rohena-Quinquilla, I.R.; Mullens, F.; Chung, E.M. MR findings in the arthropathy of relapsing polychondritis. Pediatr. Radiol. 2013, 43, 1221-1226. [CrossRef]

87. Kuwabara, M.; Shimono, T.; Toyomasu, M.; Shioyama, M.; Mitsui, Y.; Yoshinaga, E.; Kawada, A.; Hosono, M.; Murakami, T.; Kusunoki, S. "Prominent ear sign" on diffusion-weighted magnetic resonance imaging in relapsing polychondritis. Radiat. Med. 2008, 26, 438-441. [CrossRef] [PubMed]

88. Taniguchi, Y.; Nishikawa, H.; Nakayama, S.; Amano, E.; Terada, Y. Clinical implications of ultrasonography in monitoring disease activity of relapsing polychondritis. Rheumatology 2016, 55, 1250. [CrossRef]

89. Nakajima, I.; Taniguchi, Y.; Mizobuchi, T.; Kishimoto, T.; Fukushima, A.; Fukuda, K. Optic Neuropathy with Headache and Palpable Temporal Arteries Due to Hypertrophic Pachymeningitis Rather Than Giant Cell Arteritis. Ocul. Immunol. Inflamm. 2021, 2021, 1-4. [CrossRef]

90. Taniguchi, Y.; Nishikawa, H.; Amano, E.; Fujimoto, S.; Terada, Y. Ultrasonographic findings as diagnostic and follow-up tool in cranial giant cell arteritis. QJM: Int. J. Med. 2017, 110, 851-852. [CrossRef]

91. Borgia, F.; Giuffrida, R.; Guarneri, F.; Cannavò, S.P. Relapsing Polychondritis: An Updated Review. Biomed. 2018, 6, 84. [CrossRef]

92. Mathian, A.; Miyara, M.; Cohen-Aubart, F.; Haroche, J.; Hié, M.; Pha, M.; Grenier, P.; Amoura, Z. Relapsing polychondritis: A 2016 update on clinical features, diagnostic tools, treatment and biological drug use. Best Pract. Res. Clin. Rheumatol. 2016, 30, 316-333. [CrossRef]

93. Mark, K.A.; Franks, A.G., Jr. Colchicine and indomethacin for the treatment of relapsing polychondritis. J. Am. Acad. Dermatol. 2002, 46, S22-S24. [CrossRef]

94. Sharma, A.; Gnanapandithan, K.; Sharma, K.; Sharma, S. Relapsing polychondritis: A review. Clin. Rheumatol. 2013, 32, 1575-1583. [CrossRef]

95. Moulis, G.; Pugnet, G.; Costedoat-Chalumeau, N.; Mathian, A.; Leroux, G.; Boutémy, J.; Espitia, O.; Bouillet, L.; Berthier, S.; Gaultier, J.-B.; et al. Efficacy and safety of biologics in relapsing polychondritis: A French national multicentre study. Ann. Rheum. Dis. 2018, 77, 1172-1178. [CrossRef]

96. Moulis, G.; Sailler, L.; Pugnet, G.; Astudillo, L.; Arlet, P. Biologics in relapsing polychondritis: A case series. Clin. Exp. Rheumatol. 2013, 31, 937-939. [PubMed]

97. Kemta Lekpa, F.; Kraus, V.B.; Chevalier, X. Biologics in relapsing polychondritis: A literature review. Semin. Arthritis Rheum. 2012, 41, 712-719. [CrossRef] [PubMed]

98. Mellado, F.; Talesnik, E.; Castiglione, E. Azathioprine as Monotherapy for Scleritis in Relapsing Polychondritis. Ocul. Immunol. Inflamm. 2012, 20, 235-236. [CrossRef]

99. Priori, R.; Paroli, M.P.; Luan, F.L.; Abdulaziz, M.; Pezzi, P.P.; Valesini, G. Cyclosporin A in the Treatment of Relapsing Polychondritis with Severe Recurrent Eye Involvement. Rheumatology 1993, 32, 352. [CrossRef]

100. Cazabon, S.; Over, K.; Butcher, J. The successful use of infliximab in resistant relapsing polychondritis and associated scleritis. Eye 2004, 19, 222-224. [CrossRef]

101. Jabbarvand, M.; Fard, M.A. Infliximab in a Patient with Refractory Necrotizing Scleritis Associated with Relapsing Polychondritis. Ocul. Immunol. Inflamm. 2010, 18, 216-217. [CrossRef] [PubMed]

102. Shimizu, H.; Nishioka, H. Successful treatment with tocilizumab for refractory scleritis associated with relapsing polychondritis. Scand. J. Rheumatol. 2017, 46, 418-419. [CrossRef] [PubMed]

103. Farhat, R.; Clavel, G.; Villeneuve, D.; Abdelmassih, Y.; Sahyoun, M.; Gabison, E.; Sené, T.; Cochereau, I.; Titah, C. Sustained Remission with Tocilizumab in Refractory Relapsing Polychondritis with Ocular Involvement: A Case Series. Ocul. Immunol. Inflamm. 2021, 29, 9-13. [CrossRef]

104. He, Y.; Liu, H.; Ji, Z.; Zhu, B. Surgical interventions for late ocular complications of relapsing polychondritis. Am. J. Ophthalmol. Case Rep. 2016, 5, 63-66. [CrossRef]

105. Martin, N.F.; Stark, W.J.; Maumenee, A.E. Treatment of Mooren's and Mooren's-like ulcer by lamellar keratectomy: Report of six eyes and literature review. Ophthalmic Surg. 1987, 18, 564-569. 